\title{
EFFECTS OF EMITTER SPACING AND IRRIGATION RATE ON THE YIELD, QUALITY AND ENERGY REQUIREMENTS OF DRIP-IRRIGATED TOMATOES (SOLANUM LYCOPERSICUM L.)
}

\author{
KARAȘ, E. \\ Department of Biosystem Engineering, Osmangazi University, Eskisehir, Turkey \\ (e-mail:ekaras@ogu.edu.tr)
}

(Received 29 ${ }^{\text {th }}$ Oct 2019; accepted $30^{\text {th }}$ Jan 2020)

\begin{abstract}
An experiment with a randomised split plot design was performed to assess the yield, irrigation water use efficiency, energy requirements and quality of tomatoes (Lycopersicon esculentum cv. BT236 $F_{1}$ ) grown with drip irrigation on the Alpu Plain in north-western Central Anatolia, Turkey. During a trial period involving three replications from 2009 to 2011, a Class A pan was used to measure the daily evaporation values of treatments in split plots with different emitter spacing $(25 \mathrm{~cm}$ and $50 \mathrm{~cm})$ and irrigation rates (20\%, 30\%, $40 \%$ and $50 \%$ of the evaporation rate of the Class A pan). Among the results, annual evaporation during the trial period ranged from $550.9 \mathrm{~mm}$ to $721.4 \mathrm{~mm}$, and whereas higher irrigation rates afforded higher yields, lower ones afforded higher irrigation water use efficiency (IWUE). The average weight, vitamin $\mathrm{C}$ content, total soluble solid (TSS) content and $\mathrm{pH}$ values for tomatoes, all used in the proposed irrigation ratio, were $149 \mathrm{~g}, 99.18 \mathrm{mg} \mathrm{kg}^{-1}, 6.21 \%$ and 4.17 , respectively. The energy requirement of irrigation water for diesel and electric consumption changed from 42 to $105 \mathrm{~L}$ and 140.6 and $351.4 \mathrm{kWh} / \mathrm{ha}$, on average, respectively.
\end{abstract}

Keywords: drip irrigation, irrigation water use efficiency, energy consumption, tomato quality

\section{Introduction}

Tomato cultivation in Turkey plays an important economic role and it constitutes almost $40 \%$ of the total vegetable production (Aksoy and Kaymak, 2016; Guvenc, 2019). Global tomato production is currently 130 million tons. China, the European Union, India, the USA, and Turkey are known to be the top five largest tomato producers. These five producers account for $70 \%$ of global production (Eurofresh, 2016). Tomato breeding in Turkey is displaying a rising trend, which enables the country to keep its position as one of the biggest tomato producing countries in the world.

There are three cases of irrigation, which can be classified as: inadequate, excessive and optimum. First, inadequate irrigation leads to the formation of stress conditions by limiting the uptake of plant nutrients and water consumption, resulting in some quality problems and reduced yield (Lisar et al., 2012). Second, excessive irrigation causes leaching of the plant nutrients together with water and thus reduces water and nitrogen utilization efficiency (Xu et al., 2013; Huang et al., 2018; Thapa and Scott, 2019). Application of excess water to the soil not only affects seed germination and aeration of the root zone but also leads to many environmental problems such as waterlogging and salinization, contamination of groundwater's by minerals (Malash et al., 2008; Greene et al., 2016; Biswas and Kalra, 2018), nitrogen loss through leaching (Oenema et al., 2015; Shrivastava and Kumar, 2015; Musyoka et al., 2019; Rotiroti et al., 2019) and increasing irrigation costs (Kuşçu et al., 2013). Third, optimum irrigation ensures maximum water and nitrogen usage with optimal plant growth by avoiding excess water and loss of plant nutrients. Excessive usage of water not only causes a reduction in the amount of irrigated area but also more energy 
supply to carry the water into the area which is going to be irrigated. Therefore, proper management of water usage is of considerable significance for sustainable agriculture and energy conservation.

In the world's arid and semi-arid regions, water use efficiency (WUE) in general and IWUE in particular are persistent concerns as water becomes an increasingly limited resource. During the past half-century, water management has intensified in an effort to increase WUE (Medrano et al., 2015; Hatfield and Dold, 2019), which has been shown to relate closely to the method applied. Of available methods, drip irrigation, in use for nearly 50 years, has been accepted as the most efficient method of maintaining soil moisture in the root zone. Drip irrigation not only controls the amount of water used but also affords plants the efficient uptake of nutrients and pesticides (Shock, 2006). The Class A evaporation pan is one of the universally used and easy-to-control tools for water management. The results of various studies have shown that the low level of error in estimates makes Class A pan a favorable tool for the establishing of water consumption and irrigation scheduling for many plants (Ayas, 2015; Senyigit and Arslan, 2018). Numerous surveys have been conducted to assign the pan $\left(k_{p}\right)$ and crop coefficients $\left(k_{c}\right)$ of tomato in the drip irrigation method (Smajstrla and Locascio, 1990; Locascio and Smajstrla, 1996; Kırnak and Kaya, 2004; Harmanto et al., 2005; Ertek, 2011). In coarse-textured soils, the water requirements of tomatoes varied from 0.5 to 1.0 times the pan evaporation (Locascio and Smajstrla, 1989; Locascio et al., 1989), and in finer-textured soils, the results were highly similar: 0.75 times the pan evaporation for spring crops (Locascio et al., 1989) and 0.5 times the pan evaporation for fall ones (Olson and Rhoads, 1992).

Because sustainable agriculture involving the responsible use of water resources is necessary to meet the nutritional demands of expanding populations and to ensure the continuity of economic development, the study presented here was performed to assess the yield, IWUE, quality and energy requirements of drip-irrigated tomatoes using data gathered with a Class A evaporation pan.

\section{Materials and methods}

\section{Experimental site and analysis}

This research was conducted between the years 2009 and 2011 in Eskişehir-Alpu, Turkey, located at $39^{\circ} 46^{\prime} \mathrm{N}, 30^{\circ} 31^{\prime} \mathrm{E}$, with a mean elevation of $780 \mathrm{~m}$. The province is placed in a territory of a semi-arid climate with a mean temperature of $10.7^{\circ} \mathrm{C}$, the relative humidity of $62.1 \%$, annual precipitation, and evaporation are 343.5 and $976 \mathrm{~mm}$, respectively. Some of the climatical values throughout the research duration were given in Table 1 .

Soils in the study area are almost homogenous and classified as Aridisol considering United States Department of Agriculture (USDA) Soil Taxonomy (Soil Survey Staff, 2014). Three soil samples from each plot were taken using an auger from three depths $(0-30,30-60$, and $60-90 \mathrm{~cm})$. General characteristics of the soil before the experiment were given in Table 2.

Soil particle size analysis was determined by using hydrometer method (Gee and Or, 2002), $\mathrm{CaCO}_{3}$ content of the soil by Scheibler calcimeter (Loeppert and Suarez, 1996), soil organic matter by Smith-Weldon method (Nelson and Sommers, 1996), soil phosphorus content by sodium bicarbonate method (Kuo, 1996), $\mathrm{pH}$ value by using glass electrode $\mathrm{pH}$ meter (Thomas, 1996) and soil electrical conductivity (EC) value 
using standard EC electrode (Rhoades, 1996), respectively. Field capacity (FC) and wilting point (WP) moisture contents were obtained in -0.033 $\mathrm{MPa}$ and $-1.5 \mathrm{MPa}$ pressures, respectively, using a membrane extractor (Cassel and Nielsen, 1986). Available water (AW) was measured from the difference between the moisture contents of FC and WP. Bulk densities were determined by using the core method (Grossman and Reinsch, 2002). The infiltration rate was determined by a double ring infiltrometer. The AW content of the soil was $53.8 \mathrm{~mm}$ for $30 \mathrm{~cm}$ depth. The characteristics of irrigation water were determined by the methods proposed by the AWWA (American Water Works Association; Greenberg et al., 1992; Table 3).

During the research, trial plots were installed in different parts of the land having the same soil characteristics.

Table 1. Some climatic parameters throughout the research period

\begin{tabular}{|c|c|c|c|c|c|c|c|c|c|c|c|c|}
\hline \multirow{3}{*}{ Month } & \multicolumn{12}{|c|}{ Climatic parameters } \\
\hline & \multicolumn{4}{|c|}{ Temperature $\left({ }^{\circ} \mathrm{C}\right)$} & \multicolumn{4}{|c|}{ Relative humidity (\%) } & \multicolumn{4}{|c|}{ Precipitation $(\mathrm{mm})$} \\
\hline & 2009 & 2010 & 2011 & Mean $^{\mathbf{a}}$ & 2009 & 2010 & 2011 & Mean $^{a}$ & 2009 & 2010 & 2011 & Mean $^{\mathbf{a}}$ \\
\hline January & 1.0 & 2.3 & 1.0 & -0.2 & 87.2 & 69.0 & 70.9 & 74.8 & 77.2 & 31.5 & 18.3 & 36.1 \\
\hline February & 3.6 & 5.7 & 1.3 & 1.3 & 81.2 & 66.4 & 65.9 & 70.3 & 93.6 & 50.3 & 10.6 & 26.7 \\
\hline March & 5.7 & 6.7 & 4.8 & 5.0 & 76.5 & 59.3 & 64.8 & 63.5 & 55.4 & 27.7 & 16.6 & 35.6 \\
\hline April & 12.8 & 10.2 & 8.0 & 10.1 & 70.7 & 61.2 & 69.9 & 59.8 & 36.0 & 41.2 & 60.8 & 42.4 \\
\hline May & 18.6 & 16.4 & 13.7 & 14.8 & 66.4 & 55.3 & 64.9 & 57.9 & 23.7 & 5.7 & 92.3 & 42.7 \\
\hline June & 26.2 & 19.4 & 18.1 & 18.6 & 52.4 & 59.9 & 60.3 & 54.6 & 5.9 & 46.6 & 32.0 & 31.2 \\
\hline July & 33.5 & 23.3 & 23.4 & 21.4 & 53.0 & 59.8 & 51.4 & 51.1 & 1.9 & 14.3 & 20.0 & 10.5 \\
\hline August & 27.3 & 25.3 & 20.6 & 21.0 & 55.2 & 52.1 & 54.7 & 53.0 & 2.6 & 1.5 & 2.2 & 9.1 \\
\hline September & 18.6 & 19.0 & 18.3 & 16.9 & 56.4 & 59.0 & 52.7 & 54.8 & 6.4 & 26.2 & 7.1 & 13.4 \\
\hline October & 15.3 & 10.8 & 9.1 & 11.7 & 64.6 & 74.6 & 65.3 & 61.1 & 22.7 & 105.9 & 64.0 & 25.6 \\
\hline November & 6.0 & 10.0 & 1.5 & 6.0 & 68.0 & 59.9 & 62.0 & 68.5 & 14.9 & 10.1 & 0.1 & 27.6 \\
\hline December & 4.6 & 4.9 & 1.7 & 2.1 & 69.7 & 74.7 & 69.4 & 75.7 & 32.2 & 57.1 & 42.4 & 42.3 \\
\hline
\end{tabular}

a48 years mean (1957-2005)

Table 2. General physical and chemical properties of the research area

\begin{tabular}{|c|c|c|c|c|c|c|c|c|c|c|c|c|}
\hline \multirow{2}{*}{$\begin{array}{l}\text { Depth } \\
\text { (cm) }\end{array}$} & \multirow[b]{2}{*}{ pH } & \multirow{2}{*}{$\begin{array}{c}\mathbf{E C} \\
\left(\mathbf{d S} \mathbf{~ m}^{-1}\right)\end{array}$} & \multirow{2}{*}{$\begin{array}{c}\mathrm{CaCO}_{3} \\
(\%)\end{array}$} & \multirow{2}{*}{$\begin{array}{c}\mathbf{P}_{2} \mathrm{O}_{5} \\
\left(\mathrm{~kg} \mathrm{ha}^{-1}\right)\end{array}$} & \multirow{2}{*}{$\begin{array}{l}\text { Org. } \\
\text { mat. } \\
(\%)\end{array}$} & \multicolumn{3}{|c|}{ Texture (\%) } & \multirow{2}{*}{$\begin{array}{c}\text { Field } \\
\text { cap. } \\
\left(\mathrm{m}^{3} \mathrm{~m}^{-3}\right)\end{array}$} & \multirow{2}{*}{$\begin{array}{c}\text { Wilt. } \\
\text { point } \\
\left(\mathbf{m}^{3} \mathbf{m}^{-3}\right)\end{array}$} & \multirow{2}{*}{$\begin{array}{c}\text { Bulk } \\
\text { density } \\
\left(\mathrm{g} \mathrm{cm}^{-3}\right)\end{array}$} & \multirow{2}{*}{$\begin{array}{c}\text { Infiltration } \\
\text { rate } \\
\left(\mathbf{m m ~ h}^{-1}\right)\end{array}$} \\
\hline & & & & & & Sand & Silt & Clay & & & & \\
\hline 0 & 7.9 & & & & 0.78 & . & 24 & 40 & 034 & 021 & 138 & \\
\hline $30-60$ & 8.0 & 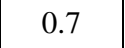 & 2 & 4 & & 35 & 25 & 41 & & 0 . & 1.34 & 11.0 \\
\hline $60-90$ & 8.0 & 0.6 & 25.9 & 59.2 & 1.53 & 34 & 23 & 43 & 0.33 & 0.21 & 1.35 & \\
\hline
\end{tabular}

Table 3. Characteristics of irrigation water used in the study

\begin{tabular}{c|c|c|c|c|c}
\hline \multicolumn{2}{c|}{ Cations $\left(\mathbf{m e q ~ l}^{-\mathbf{1}}\right)$} & \multicolumn{2}{c}{ Anions $\left(\mathbf{m e q ~ \mathbf { l } ^ { - 1 }}\right)$} & $\mathrm{pH}$ & \multicolumn{2}{c}{ Other parameters } \\
\hline $\mathrm{Na}^{+}$ & 2.66 & $\mathrm{CO}_{3}^{--}$ & 0.0 & $\left.\mathrm{EC}(\mathrm{dS} \mathrm{m})^{-1}\right)$ & 1.00 \\
$\mathrm{~K}^{+}$ & 0.04 & $\mathrm{HCO}_{3}^{-}$ & 4.42 & $\mathrm{~B}\left(\mathrm{mg} \mathrm{l}^{-1}\right)$ & 0.0 \\
$\mathrm{Ca}^{++}$ & 4.14 & $\mathrm{Cl}^{-}$ & 1.44 & $\mathrm{SAR}$ & 1.25 \\
$\mathrm{Mg}^{++}$ & 4.89 & $\mathrm{SO}_{4}^{--}$ & 5.87 & & \\
\hline Total & 11.73 & Total & 11.73 & & \\
\hline
\end{tabular}




$$
-1850 \text { - }
$$

\section{Irrigation scheduling}

Irrigation scheduling was prepared based on the water holding capacity (WHC) for top 0-30 cm depth. The net irrigation depth $\left(\mathrm{d}_{\text {net }}\right)$, which is accepted as $40 \%$ of field capacity, was about $25.0 \mathrm{~mm}$ for the experimental area. Amounts of waters to be applied were calculated by the multiplication of $d_{n e t}$ with evaporation rates. Irrigation water was applied when the evaporated water from the Class A pan reached to the calculated $d_{n e t}$ value of the soil. There was not a constant irrigation interval during the research period. The coefficient of Class A pan $\left(k_{p}\right)$ was assumed as 1.00 for evaporation calculations. Wetting areas were determined by using the method suggested by Keller and Bliesner (1990). The maximum and minimum wetting areas were found as $30.7 \%$ and $18.5 \%$, respectively.

The irrigation water $\left(\mathrm{I}, \mathrm{m}^{3}\right)$ amount was calculated using the following equation:

$$
\mathrm{I}=\mathrm{A} \times \mathrm{E}_{\mathrm{p}} \times k_{p} \times \mathrm{E}_{\mathrm{r}}
$$

where $\mathrm{A}$ is the plot area $\left(\mathrm{m}^{2}\right) ; \mathrm{E}_{\mathrm{p}}$ is the accumulated evaporation for irrigation interval $\left(10^{-3} \mathrm{~mm}\right) ; k_{p}$, pan coefficient (1.00); $\mathrm{E}_{\mathrm{r}}$ is the evaporation rate $(\%)$.

Daily evaporation data were obtained from the weather station placed in the study area. Before the experiment, all plots were irrigated until they reach field capacity for the depth of 0-30 $\mathrm{cm}$. Subsequent irrigations were carried out when the cumulative evaporation amount measured daily from the class A pan reached $25 \mathrm{~mm}$.

In this study, the moisture changes in the soil were checked by three tensiometers measuring soil moisture to 0-90 cm depth $(0-30,30-60$ and $60-90 \mathrm{~cm})$. Soil moisture measurements were followed in only one replicate of the experimental subjects. Since the maximum amount of irrigation water applied in each irrigation was $25 \mathrm{~mm}$, no pressure changes were observed in the tensiometers at depths below $30 \mathrm{~cm}$. Thus, no deep percolation was detected under the depth of $30 \mathrm{~cm}$ in the measurements made during the trial.

\section{Experimental design}

The experiment was organized as a split-plot randomized block design with three replications in 24 plots, each measuring $31.2 \mathrm{~m}^{2}(6.0 \mathrm{~m}$ length $\times 5.2 \mathrm{~m}$ width), with a separate strip of $2 \mathrm{~m}$ between them (Figs. 1 and 2).

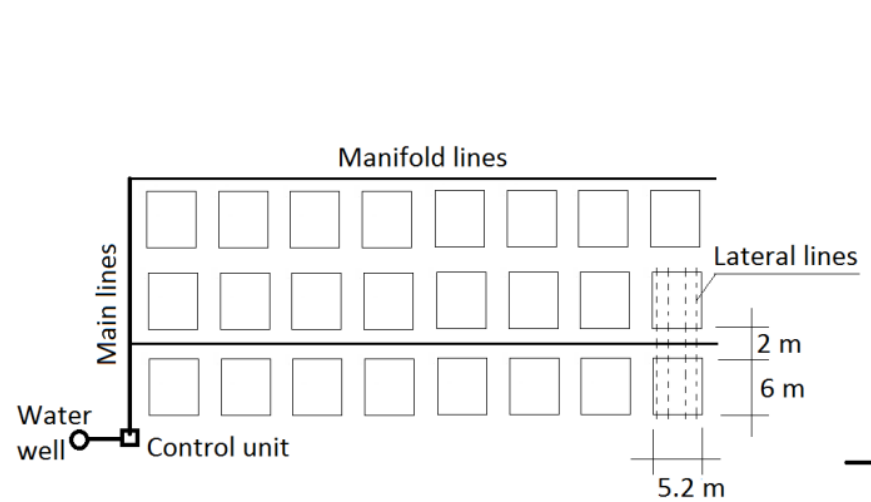

(a)

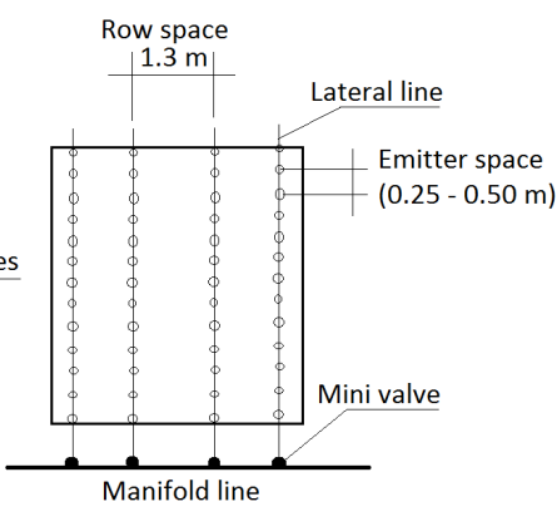

(b)

Figure 1. General view of the irrigation system in the research area (a), and lateral lines, row and emitter spaces $(b)$ 


$$
\text { - } 1851 \text { - }
$$

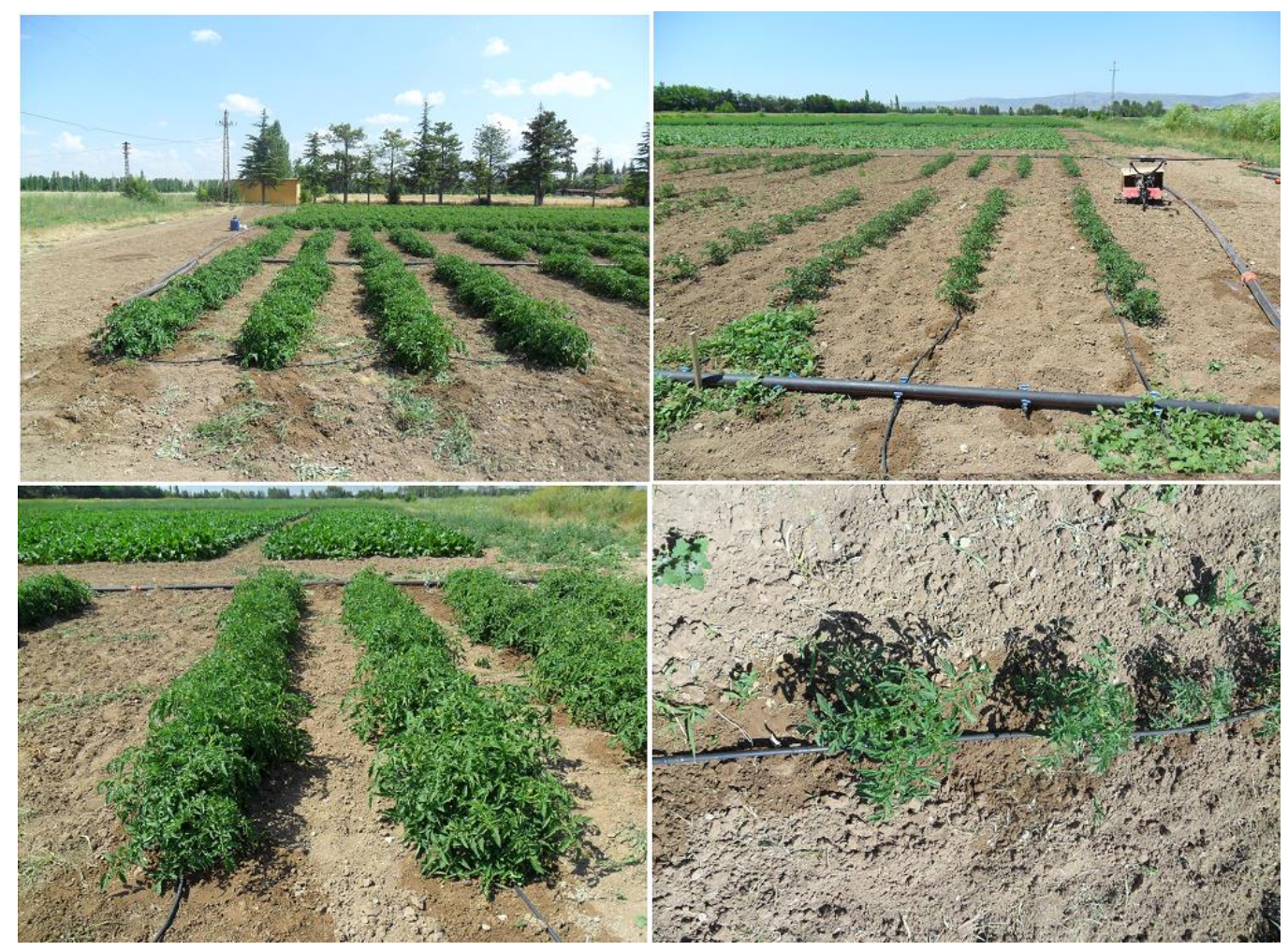

Figure 2. General view of the parcels and plants in the trial area

The irrigation water, pumped from a deep well (15 $\mathrm{m}$ in depth), was conveyed to experimental plots with main and sub-main poly-etylen (PE) lines of $75 \mathrm{~mm}$ diameter. The control unit of the irrigation system had a hydro-cyclone filter, a sand filter, a screen filter, a mesh filter, pressure gauges, and a fertilizer tank with a dosage pump. Lateral lines with a diameter of $16 \mathrm{~mm}$ were laid down perpendicular along each tomato row at $1.3 \mathrm{~m}$ spacing. The flow rate of the drippers in the lateral lines was $4 \mathrm{~L} / \mathrm{h}$ at a working pressure of 1 atmosphere. The evaporation rates of Class A pan (A: 20\%, B: $30 \%$, C: $40 \%$, and D: $50 \%$ ) and the emitter spaces (a: $25 \mathrm{~cm}$, and b: $50 \mathrm{~cm}$ ) were selected as main and subplot in the experiment, respectively. Two weeks old tomato seedlings were transplanted into the plots in the middle of May. The chemical fertilizing applications were carried out as suggested by Hartz (2006). There were four lateral lines in each plot. Row spaces between lateral lines were $1.3 \mathrm{~m}$. There were 12 plants in each line and a total of 48 plants in each plot. IWUE values were calculated according to the method proposed by Howell (2001). The energy requirement for irrigation water is calculated considering diesel and electric systems. Statistical analyses were achieved with SPSS 17.0 (SPSS Inc, 2008). Data were tested by ANOVA with the factors years, evaporation rates, drip space, and yield and the possible interaction between both factors. Duncan's multiple comparison test was used to determine mean differences.

\section{Tomato quality analysis}

Samples for quality analysis were made in the first week of September to determine the fruit weight, $\mathrm{pH}$, TSS and vitamin $\mathrm{C}$ values in tomato fruit in all trial years.

Fruit Weight: The average weights of tomato fruits randomly taken around $5 \mathrm{~kg}$ from the middle rows of the experimental plots were determined. 


$$
-1852 \text { - }
$$

$p H$ : Tomato juice was prepared by pouring the fruits into the blender for $10 \mathrm{~min}$. Then, buffer solutions were prepared by $\mathrm{pH}$ meter, $10 \mathrm{~mL}$ of tomato juice was added into a $50 \mathrm{~mL}$ beaker. The $\mathrm{pH}$ of the obtained sample was measured using a $\mathrm{pH}$ meter (pH-Vision, model 6071, Taiwan).

Total soluble solids (TSS): The TSS was determined as a percentage $(\%)$ value at $20^{\circ}$ using a digital refractometer (Atago Co. Ld., Japan) in three replicates of $1 \mathrm{~kg}$ sample.

Vitamin $C$ content: It was determined in tomato puree using the method determined by Riemschneider et al. (1976).

\section{Energy requirements}

In the Alpu plain where the experiment is conducted, irrigation water is commonly taken from deep ( $>6 \mathrm{~m}$ ) wells using electric submersible pumps and from shallow wells $(\leq 6 \mathrm{~m})$ using diesel-consuming motor pumps. The aquifer formation in the Alpu plain is ground alluvial. Its thickness varies between 5-95 $\mathrm{m}$. The depths of the drilling wells drilled in the plain are between $11-250 \mathrm{~m}$ and their yield is $10-50 \mathrm{~L} \mathrm{~s}^{-1}$.

The average well flow rates of $50 \mathrm{~m}^{3} \mathrm{~h}^{-1}$ are considered as two different sources, diesel and electric. In order to calculate the energy need, the energy consumption of the $17 \mathrm{hp}$ diesel fuel consuming engine pump, which is widely used in the Alpu plain, is taken into consideration. The diesel fuel consuming pump is used to supply water from wells that are no deeper than $6 \mathrm{~m}$ and the hourly flow rate of $2 / 3$ gas is $50 \mathrm{~m}^{3}$. The energy requirement of the electric submersible pump with an hourly capacity of $50 \mathrm{~m}^{3}$ from deep wells up to $50 \mathrm{~m}$ in the study area is taken into consideration.

\section{Results and discussion}

\section{Yield and irrigation water use efficiency}

The use of Class A pan is a common practice in the field trials for the calculation of plant water consumption and irrigation water amounts. Although the coefficient of Class A pan $\left(k_{p}\right)$ was assumed as 1.00 for evaporation calculations in this study, many studies used different coefficients such as 0, 0.25, 0.50, 0.75, and 1.00 (Locascio and Samjstrla, 1996), 0.75 (Harmanto et al., 2005), and 0.80 (Kirnak and Kaya, 2004). These studies have shown that the highest yields were obtained by assuming a pan coefficient of 0.75 and 1.00 .

The effects of deficit irrigation on yield, seasonal water application (IW), and IWUE are given in Table 4 and Figures 3 and 4.

Table 4. Effects of deficit irrigation on yield, seasonal water application and IWUE

\begin{tabular}{|c|c|c|c|c|c|c|c|c|c|c|c|c|}
\hline \multirow{2}{*}{$\begin{array}{l}\text { ER }^{*} \\
(\%)\end{array}$} & \multicolumn{4}{|c|}{ Yield $\left(\mathrm{t} \mathrm{ha}^{-1}\right)$} & \multicolumn{4}{|c|}{ IW $\left(\mathrm{m}^{3} \mathrm{ha}^{-1}\right)$} & \multicolumn{4}{|c|}{ IWUE $\left(\mathrm{kg} \mathrm{m}^{-3}\right)$} \\
\hline & 2009 & 2010 & 2011 & & 09 & 2010 & 2011 & $\mathbf{N}$ & 2009 & 2010 & 2011 & Mean \\
\hline $20 \%$ & $133.3^{b}$ & & & & & & & & & & & \\
\hline $30 \%$ & $129.9^{b}$ & $88.3^{\mathrm{a}}$ & $84.3^{\mathrm{a}}$ & $102.1^{\mathrm{b}}$ & 50 & 60 & 1840 & 1867 & $60.03^{b}$ & $55.62^{\mathrm{a}}$ & & \\
\hline $40 \%$ & $175.6^{\mathrm{a}}$ & $93.4^{\mathrm{a}}$ & $85.7^{\mathrm{a}}$ & $118.3^{\mathrm{a}}$ & 2890 & 2200 & 2450 & 2513 & $60.88^{b}$ & $42.42^{b}$ & $35.03^{c}$ & $46.11^{c}$ \\
\hline $50 \%$ & $161.6^{\mathrm{a}}$ & $107.0^{\mathrm{a}}$ & $91.7^{\mathrm{a}}$ & $120.1^{\mathrm{a}}$ & 3610 & 2760 & 3070 & 3147 & $44.82^{c}$ & $38.85^{b}$ & $29.85^{\mathrm{d}}$ & 37.84 \\
\hline Mean & $150.2^{\mathrm{a}}$ & $90.0^{\mathrm{b}}$ & $82.1^{\mathrm{c}}$ & & 2525 & 1930 & 2148 & & $64.55^{\mathrm{a}}$ & $49.57^{b}$ & $41.19^{c}$ & \\
\hline
\end{tabular}

*ER: Evaporation rate of Class A pan, IW: Seasonal water application (mm), IWUE: Irrigation water use efficiency $\left(\mathrm{kg} \mathrm{m}^{-3}\right)$ 


$$
-1853 \text { - }
$$

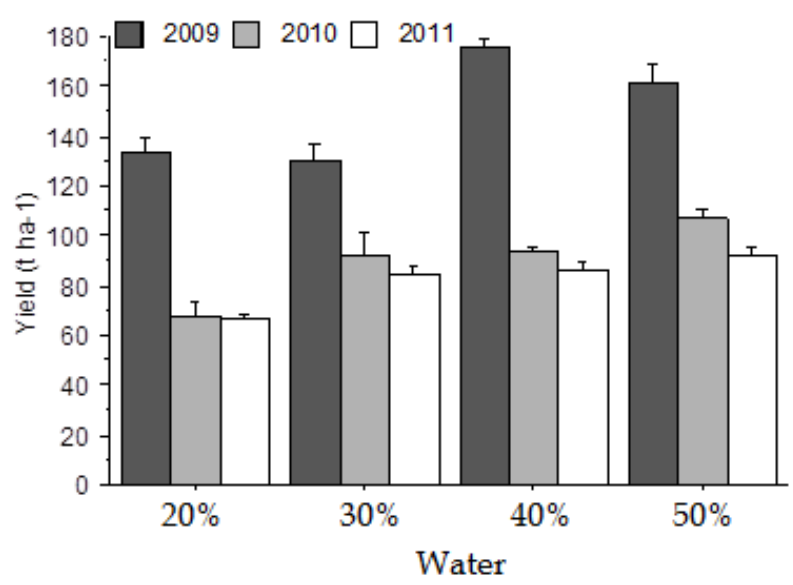

Figure 3. Effects of deficit irrigation (\% of ER) on the yield of tomato (t/ha)

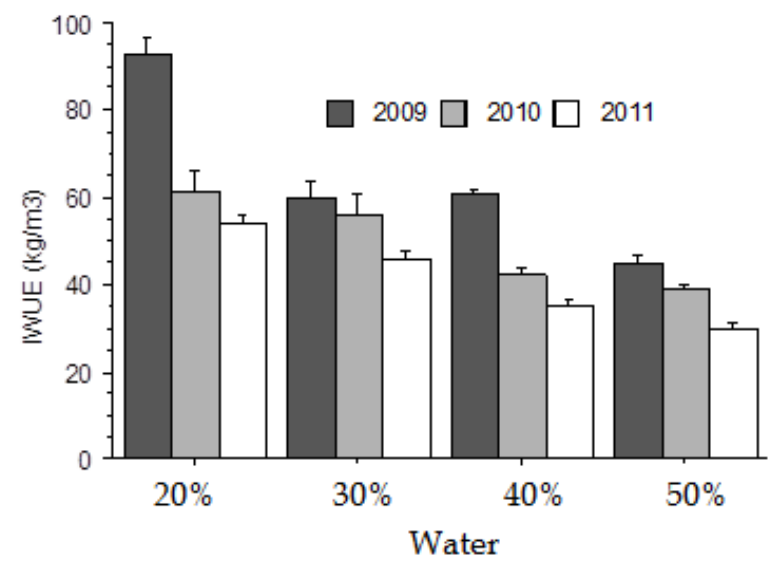

Figure 4. Effects of deficit irrigation (\% of ER) on IWUE $\left(\mathrm{kg} / \mathrm{m}^{3}\right)$

There were significant differences between the years studied. The yields obtained in the first year of the study (2009) were higher than that of the following two years (2010 and 2011). The reason for reduced yield in these years could be related to the negative effects of climatic conditions in the growing season (earlier frost occurring date) and disease (Early blight, Septoria leaf spot, Fusarium wilt, Verticillium wilt) development. In 2009, while the highest yield was obtained from the subject where $40 \%$ of evaporation was applied (40\% of ER) as $175.6 \mathrm{t} \mathrm{ha}^{-1}$, the yield of the highest seasonal water application (50\% of ER) was found as $161.6 \mathrm{t} \mathrm{ha}^{-1}$. The lowest yields were obtained from $20 \%$ and $30 \%$ of ER as 133.3 and $129.9 \mathrm{t} \mathrm{ha}^{-1}$, respectively (Fig. 3). While the amount of seasonal water application is twice between the subjects $20 \%$ and $40 \%$ of ER, the amount of increase in yield is found just as $31.7 \%$, in 2009 . Except for 2009, the highest and the lowest yields were obtained from the subjects where the highest and the lowest irrigation waters were applied, respectively. The minimum and maximum yields per hectare were found as 67.6 and 107.0 tons for $20 \%$ and $50 \%$ of ER for 2010, respectively. The amount of seasonal water application was 1100 and $2760 \mathrm{~m}^{3}$ for these subjects. Although the amount of irrigation water applied in 2011 was relatively higher than that of 2010 , the yields obtained were almost similar for the same subjects. The highest yield per hectare was obtained from 50\% of ER as 91.7 tons, and 


$$
-1854 \text { - }
$$

the lowest from $20 \%$ of ER as 66.4 tons. In general, the increase in the amount of water applied to the increased yield obtained. However, there was no clear trend between the amount of water applied and the extent of the response. While the amount of applied water between $50 \%$ of ER and $20 \%$ of ER was 2.5 folds, the amount of increase in yield was found as $21.2 \%, 58.3 \%$, and $38.1 \%$ for years 2009,2010 , and 2011, respectively.

The values of IWUE calculated for various deficit irrigation practices in all experimental years are summarized in Table 4 and Figure 4. The IWUE gradually decreased from $50 \%$ of ER to $20 \%$ of ER, providing that tomato uses the water more efficiently under stress conditions. As expected, the highest and the lowest IWUE values were obtained from $20 \%$ and $50 \%$ of ER, respectively. Irrigation time and frequency play an important role in tomato production and productivity, hence in IWUE. Chen et al. (2013), have found that full irrigation at the seedling stage did not affect tomato yield and fruit quality. On the other hand, tomato yield decreased significantly depending on the degree of water stress applied during flowering and fruit development periods. Marouelli et al. (2004), have stated that the highest WUE in tomato occurs between flowering and fruit formation stages. Therefore, it is necessary to plan irrigation considering the water content of the soil at different growth stages of the plant. Continuous monitoring of soil moisture content is of vital importance. Results of this study have shown that even under deficit irrigation conditions high yields can be achieved by continuous monitoring of soil moisture.

All crops take water from wherever it is most readily available within the root zone. Most of the studies conducted on tomato are focused on the effective root depth of 50$60 \mathrm{~cm}$. However, it is well known that on average $40 \%$ of water uptake is assumed to be taken from the upper quarter of the rooting depth, and $30 \%$ from the second quarter. Therefore, $25-30 \mathrm{~cm}$ rooting depth is responsible for $70 \%$ of water uptake. This study demonstrated that, even under deficit irrigation conditions, $30 \mathrm{~cm}$ rooting depth can be considered as an effective rooting depth for tomato and performing irrigation when $40 \%$ of the available water holding capacity calculated for $30 \mathrm{~cm}$ soil depth is evaporated from the Class A pan can give fairly good results. Emitter spacing did not affect yield and IWUE.

\section{Fruit quality}

The results of the application subjects on fruit weight, $\mathrm{pH}$, TSS, and vitamin $\mathrm{C}$ are given in Figure 5.

Fruit Weight: The effect of irrigation water on fruit weight was significant both in terms of annual and amount of irrigation water. The average fruit weights of 2009 and 2011 were in the same group with 159.25 and 156.25 grams respectively, while the results obtained in 2010 constituted another group with 138.58 grams. Differences between irrigation practices led to different fruit weights each year. The highest fruit weight was obtained from the highest irrigation application in three years. In 2009, evaporation ratio of $50 \%$ gave the highest fruit weight with statistical group a followed by $30 \%, 40 \%(a b)$ and $20 \%$ with group b. Similarly, evaporation ratio of $50 \%$ was the best application for fruit weight while the lowest value was observed in evaporation rate of $20 \%$ in 2010 . In 2011, 50\% was the first statistical group while the others followed with the same group.

The effect of deficit irrigation on tomato fruit quality has been investigated in many studies (Colla et al., 1999; Machade and Oliviera, 2005; Patane and Cosentino, 2010; Patane et al., 2011; Garnett et al., 2013; Cantore et al., 2016; Hashem et al., 2018). The 
effect of limited irrigation on fruit quality is generally inversely related to fruit yield. The results show the effect of irrigation water applied, but their impact on quality is unstable. Fruit weight is a factor that is largely affected by the amount of irrigation water or applied water stress. Some studies indicate that fruit weight increases with irrigation water, whereas stress conditions decrease. In our study, fruit weights were affected by water stress in the other two years (2010 and 2011) except in the first year (2009). In general, the highest amount of irrigation water applied gave higher fruit weight values. According to the three-year average results of the study, it is understood that all the subjects except $50 \% \mathrm{ER}$, where the highest irrigation water is applied, give the same average fruit weight values statistically. Mitchell et al. (1991) reported the decrease in tomato fruit weights due to deficit water and salinity as $37 \%$ and $42 \%$, respectively. Similar results are pointed out by Yurtseven et al. (2005), It was observed that raising salinity levels in irrigation water resulted in a dramatic decrease in fruit weight. Birhanu and Tilahun (2010) and Patane et al. (2011) observed that deficit irrigation reduces fruit weight due to water stress. In the study conducted by Helyes et al. (2012), fruit weights obtained by the cut off irrigation in the early period with full irrigation in tomato did not differ statistically. However, the average fruit weights obtained by cultivation under rainfed conditions were lower than full irrigation.
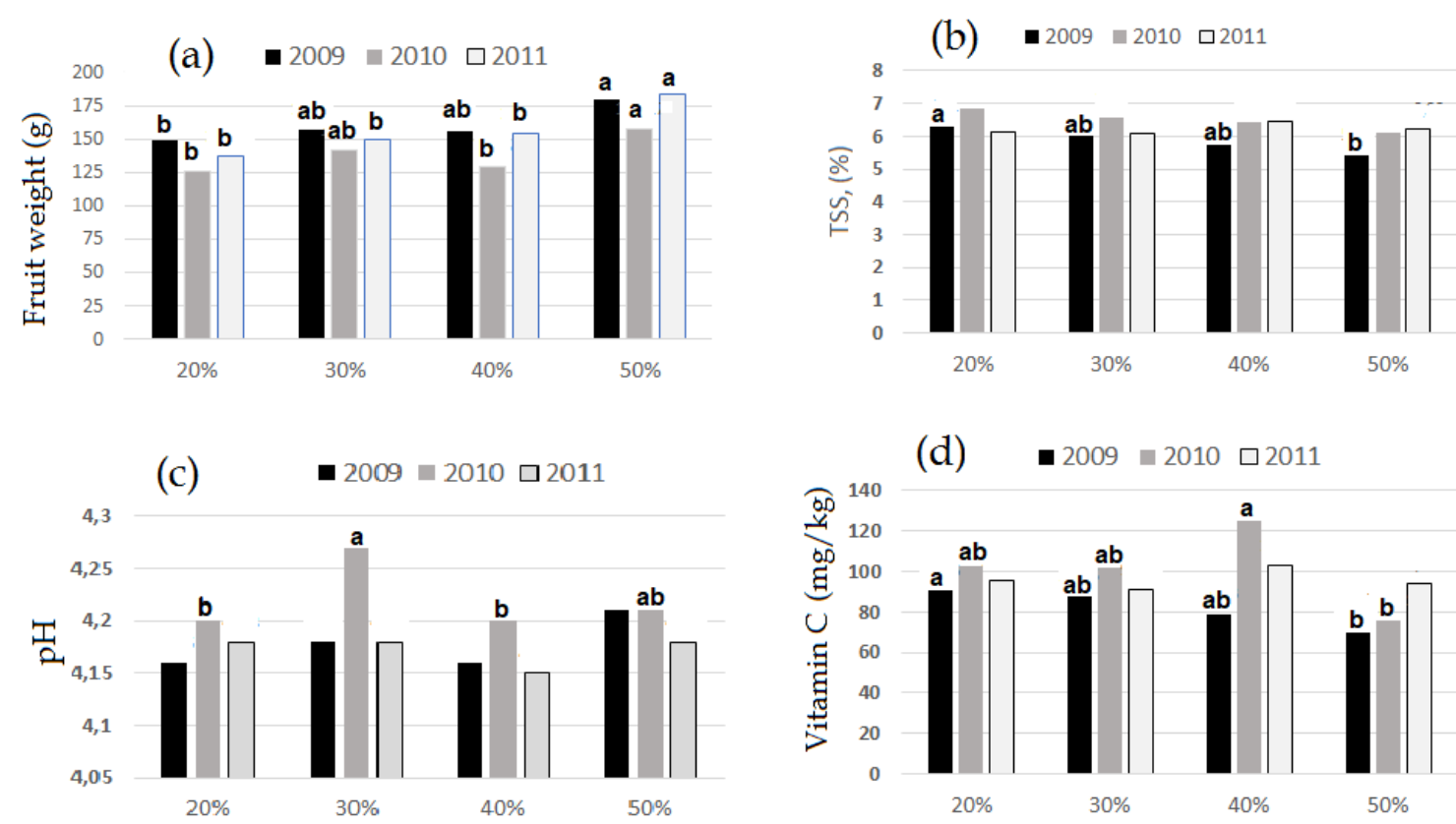

Figure 5. The effects of applied irrigation water on fruit weight (a), TSS (b), pH (c), and Vitamin $C(d)$

TSS: The TSS contents differed both in terms of year and amount of irrigation water. In general, the average values for 2010 and 2011 are in the same group and 2009 is in another group. In terms of average values of the issues, the highest TSS content was obtained as $6.43 \%$ on the lowest application rate (20\% of ER). The results obtained in 2009 in terms of irrigation practices gave the same result as the general average. The data for this year gave the highest value of $6.31 \%$ for $20 \%$ of ER and $5.42 \%$ for $50 \%$ of ER. The impact of irrigation practices for 2010 and 2011 was statistically insignificant. The values obtained in terms of TSS followed a decreasing trend for the first two years 
due to the decrease in the amount of irrigation water: TSS $=6.6-0.291 \mathrm{ER}\left(\mathrm{r}^{2}=0.996\right)$ equation (TSS as Brix, and ER: Applied water as Evaporation Rate, \%) for 2009 and TSS $=7.085-0.243$ ER $\left(r^{2}=0.983\right)$ for 2010 . No meaningful equality has occurred for 2011.

In Mohammed et al.'s (2018) study, considering the vegetative, flowering and fruit maturity stages during tomato cultivation, the lowest TSS values occurred in the control plants, which were not exposed to any water stress, whereas the highest occurred when deficit water was applied during fruit maturity. Other researchers, by contrast, have demonstrated the inverse relationship between deficit irrigation and TSS (ZegbeDominguez et al., 2003; Garcia and Barrett, 2006; Helyes et al., 2012; Kuşçu et al., 2014). Contrary to those results, Dumas et al. (2003) observed that the effect of deficit water on TSS content was negligible, and Yurtseven et al. (2005) found that TSS content in tomatoes increased by $100 \%$ when exposed to irrigation water with a salinity of $10 \mathrm{dS} \mathrm{m} \mathrm{m}^{-1}$ compared to controls. Expanding upon those results, Birhanu and Tilahun (2010), who observed that moderate drought stress caused significant increases in the TSS content of tomatoes, proposed that the increased TSS content of tomatoes grown in soil with a water deficit directly related to their decreased water content. Added to that, Banjaw et al. (2018) found that TSS content in tomatoes increased with stress and varied among cultivars, while their water content decreased. Last, Mitchell et al. (1991) noted that terminating irrigation 50 days before harvest prompted significant increases in the quality of tomatoes in terms of TSS content.

$p H$ : While the difference in the amount of irrigation water applied for $\mathrm{pH}$ values was observed only in 2010, there was no difference between 2009 and 2011 data. When the general average results of the years are compared, 2010 constitutes group a, while 2009 and 2011 constitute 4.18 and 4.17, respectively. No effect of the mean values of irrigation water on $\mathrm{pH}$ was determined.

The $\mathrm{pH}$ of tomatoes is determined primarily by the acid content of the fruit. The acidity of the fruit is also important as a contributor to the flavor of the tomato products (Anton et al., 2010). The acidity values of vegetables and fruits vary according to species, varieties, growing period and maturity. According to the US Food and Drug Administration Food Safety and Applied Nutrition Center (CFSAN), the acidity value of fresh tomatoes ranges from 4.3-4.9, while the $\mathrm{pH}$ range for canned tomatoes and tomato paste is 3.5-4.7. The range for tomato juice is 4.1-4.6. The acidity of fresh tomatoes may be closely related to their maturity. As the tomato fruit ripens, its acidity decreases and the $\mathrm{pH}$ approaches 4.9 ends of the previously described range. Canned tomatoes are typically more acidic than fresh tomatoes due to the effect of canning, and Canned tomatoes have a pH of about 3.5 (Mohammed et al., 1999; CFSAN, 2019). According to Hernández-Suarez et al. (2008), tomato fruit with a $\mathrm{pH}$ below 4.5 is classified as acidic. $\mathrm{pH}$ is important due to acidity influences the thermal processing conditions required for producing safe products (Garcia and Barrett, 2006). Based on this information, it can be said that the $\mathrm{pH}$ value of tomato fruit juice obtained in our research is all acidic. Many research findings show that the amount of irrigation water applied is not effective on the $\mathrm{pH}$ of tomato fruit juice. These results are consistent with those reported by Nuruddin et al. (2003) and Amor and Amor (2007). In contrast, Wahb-Allah and Al-Oman (2012) mention the positive effect of deficit water on $\mathrm{pH}$. Increased salinity levels in irrigation water caused by the production of smaller sized fruits, but this leads to a decrease in the $\mathrm{pH}$ of the fruit juice (Yurtseven et al., 2005). 


$$
-1857 \text { - }
$$

Vitamin $C$ : The rates of irrigation water applied were statistically different in both year and rate. Although the year 2010 data is the year in which the highest value is obtained, it is in the same group in 2011 as the general average. On the other hand, 81.80 in 2009 constituted the other group. According to 2009 data, the highest vitamin C value was obtained from the issue of $20 \%$ of ER with the lowest water application, the $40 \%$ of ER subject was in the (ab) group, and the $30 \%$ and $50 \%$ of ER subjects were in the (ab) group. The results in 2010 differed from the previous year; this time $40 \%$ ER constitutes group (a) an alone, $50 \%$ of ER group (ab) and $20 \%$ and $30 \%$ both group (b). The 2011 data showed no difference in terms of vitamin $\mathrm{C}$ values measured according to the applied irrigation water data. According to the 3-year average data, the differences in irrigation water issues on vitamin $\mathrm{C}$ were observed statistically. According to the results of the research, there is an inverse relationship between the amount of vitamin $\mathrm{C}$ and evaporation rates, depending on the water stress applied in general. As the amount of irrigation water applied in 2009 and 2010 increased, vitamin C values decreased. According to Dumas et al. (2003), vitamin C content in tomato depends on the growing season, favorable plant nutrients and environment. Studies are indicating that the change in the scope of vitamin $\mathrm{C}$ is an element of increasing plant water consumption and variety features (Mahajan and Singh, 2006; Mitchell et al. 1991). Lovelli et al. (2017) found that no significant effects were observed on the vitamin $\mathrm{C}$ content.

\section{Energy requirements}

Energy requirements for diesel fuel and electric powered pumps of the irrigation subjects are shown in Figure 6.
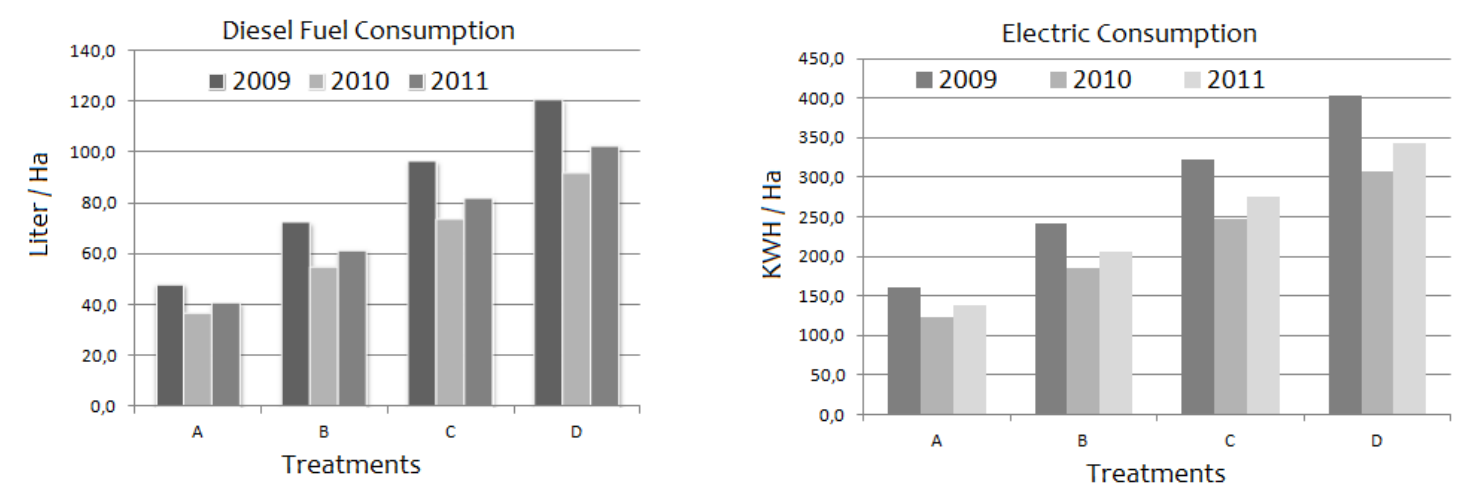

Figure 6. Energy requirements for diesel fuel and electric powered pumps of the treatments

While diesel fuel consumption for the irrigation subject is changing from 42 to $105 \mathrm{~L}$, electric consumption ranged between 140.6 and $351.4 \mathrm{kWh} / \mathrm{ha}$, averagely.

In the study, considering the distance between the lateral lines, the equality that can be used in the calculation of the amount of irrigation water that can be applied in heavy textured soils is found as follows:

$$
\mathrm{Q}=8663.3 \mathrm{X}^{-0,996}\left(\mathrm{r}^{2}=0.99\right)
$$

where Q: irrigation water per hectare as $\mathrm{m}^{3} ; \mathrm{X}$ : lateral line spacing $(\mathrm{X}, \mathrm{cm})$. 


\section{Conclusion}

Banjaw (2017) states that deficit irrigation is an optimization strategy implemented in a way that there is no decrease in yield during certain growth periods of the plant. Restricted irrigation provides storage of water in areas with water shortage and the use of water saved during long dry periods to ensure sustainable yield. Reducing irrigation water is an opportunity to save water by reducing production costs, as well as minimizing leachable nutrients such as nitrogen by deep infiltration.

The research that used the pan coefficient in tomato irrigation time planning has been carried out under various soil, climatic conditions. Application variations such as pan coefficient, lateral and emitter spacing, irrigation interval can give different results in a similar climate, even in the same climatic and soil conditions. Therefore, it is not possible to make generalizations and to say of the existence of a single truth. The results obtained with this can be evaluated by comparing the data within them.

The amount of evaporating water from the class A pan represents a saturated condition in which there is no water shortage in the soil. Although the plant's developmental status (i.e. root and leaf growth) varies, their response to water stress is also different. In many studies conducted using class A pan, a constant Kpc was used during the growing period. However, the results obtained from many studies showed that plants' reactions to periodic water constraints were not the same. Considering this situation, the use of different coefficients for each period can be one of the solutions that can be used for irrigation planning by using Class A pan for optimum water and nutrient management and saving water in the root zone. It may be possible to develop regional equities or use of coefficients, taking into account the climate and soil conditions.

An equation was developed to be used for different lateral spacing for heavy textured soils, taking into account the proposed evaporation rates obtained. In that process, lateral intervals and the amounts of irrigation water required for each lateral interval were analyzed together. When different lateral spacings are used, the volume of irrigation water per hectare can determine.

The root system of many plants in the vegetable group is shallow depth. Optimal irrigation programs can be developed on soils with different soil structures without causing deep penetration and therefore no leaching and stress on plants. For this reason, future research programs should be focused on improving IWUE and nutrient utilization efficiencies, especially by preventing water and nutrient losses. In this way, significant savings in irrigation energy can be achieved.

\section{REFERENCES}

[1] Aksoy, A., Kaymak, H. Ç. (2016): Outlook on the Turkish tomato sector. - Iğdır Univ. J. Inst. Sci. Tech. 6(2): 121-129.

[2] Amor, M. A., Amor, F. M. (2007): Response of tomato plants to deficit irrigation under surface or subsurface drip irrigation. - Journal of Applied Horticulture 9(2): 97-100.

[3] Anthon, G. E., LeStrangeb, M., Barretta, D. M. (2011): Changes in pH, acids, sugars and other quality parameters during extended vine holding of ripe processing tomatoes. $-\mathrm{J}$ Sci Food Agric. DOI: 10.1002/jsfa.4312.

[4] Ayas, S. (2015): The effects of different regimes on tomato (Lycopersicon lycopersicum L. var. Hazal) yield and quality characteristics under unheated greenhouse conditions. Bulgarian Journal of Agricultural Science 21(6): 1235-1241. 


$$
-1859 \text { - }
$$

[5] Banjaw, D. T., Megersa, H. G., Lemma, D. T. (2017): Effect of water quality and deficit irrigation on tomatoes yield and quality: a review. - Adv Crop Sci Tech 5: 295. DOI: 10.4172/2329-8863.1000295.

[6] Birhanu, K., Tilahun, K. (2010): Fruit yield and quality of drip-irrigated tomato under deficit irrigation. - African Journal of Food, Agriculture, Nutrition and Development 10(2).

[7] Biswas, J. C., Kalra, N. (2018): Effect of waterlogging and submergence on crop physiology and growth of different crops and its remedies: Bangladesh perspectives. Saudi J. Eng. Technol. 3(6): 315-329.

[8] Cantore, V., Lechkar, O., Karabulut, E., Sellami, M. H., Albrizio, R., Boari, F., Stellacci, A. M., Todorovic, M. (2016): Combined effect of deficit irrigation and strobilurin application on yield, fruit quality and water use efficiency of "cherry" tomato (Solanum Lycopersicum L.). - Agr. Water Manage. 167: 53-61.

[9] Cassel, D. K., Nielsen, D. R. (1986): Field Capacity and Available Water Capacity. - In: Klute, A. (ed.) Methods of Soil Analysis. Part I. Physical and Mineralogical Methods, Agronomy Monograph No. 9, Soil Science Society of America, Madison, WI, pp. 901926.

[10] CFSAN (2019): Can you tell me about the acidity in tomatoes. http://whfoods.org/genpage.php?pfriendly=1\&tname=dailytip\&dbid=383 (accessed on 24.10.2019).

[11] Chen, J., Kang, S., Du, T., Qiu, R., Guo, P., Chen, R. (2013): Quantitative response of greenhouse tomato yield and quality to water deficit at different growth stages. Agricultural Water Management 129(C): 152-162. DOI: 10.1016/j.agwat.2013.07.011.

[12] Colla, G., Casa, R., Locascio, B., Saccardo, F., Temperini, O., Leoni, C. (1999): Responses of processing tomato to water regime and fertilization, in Central Italy. - Acta Hortic. 487: 531-5.

[13] Dumas, Y., Dadomo, A., Di Lucca, G., Grolier, P. (2003): Effects of environmental factors and agricultural techniques on the antioxidant content of tomatoes. - J Sci Food Agric 83: 369-382.

[14] Ertek, A. (2011): Importance of pan evaporation for irrigation scheduling and proper use of crop-pan coefficient (Kcp), crop coefficient (Kc) and pan coefficient (Kp). - African Journal of Agricultural Research 6(32): 6706-6718.

[15] Eurofresh (2016): Around the world: tomatoes. - https://www.eurofreshdistribution.com/news/around-world-tomatoes.

[16] Garcia, E., Barrett, D. M. (2006): Peelability and yield of processing tomatoes by steam or lye. - Journal of Food Processing and Preservation 30(1): 3-14.

[17] Garnett, T., Appleby, M. C., Balmford, A., Bateman, I. J., Benton, T. G., Bloomer, P., Burlingame, B., Dawkins, M., Dolan, L., Fraser, D., Herrero, M., Hoffmann, I., Smith, P., Thornton, P. K., Toulmin, C., Vermeulen, S. J., Godfray, H. C. (2013): Sustainable intensification in agriculture: premises and policies. - Science 341: 33-4.

[18] Gee, G. W., Or, D. (2002): Particle Size Analysis. - In: Dane, J. H., Topp, G. C. (eds.) Methods of Soil Analysis. Part 4: Physical Methods. Soils Science Society of America, Book Series No. 5, Madison, WI, pp. 255-293.

[19] Greenberg, A. E., Clesceri, L. S., Eaton, A. D. (1992): Standard Methods for the Examination of Water and Wastewater. 18th Ed. - Am. Public Health Assoc., Am. Water Works Assoc., and Water Environment Fed: Washington, DC.

[20] Greene, R., Timms, W., Rengasamy, P., Arshad, M., Cresswell, R. (2016): Soil and Aquifer Salinization: Toward an Integrated Approach for Salinity Management of Groundwater. - In: Jakeman, A. J., Barreteau, O., Hunt, R. J., Rinaudo, J. D., Ross, A. (eds.) Integrated Groundwater Management. Springer, Cham. https://doi.org/10.1007/978-3-319-23576-9_15. 
[21] Grossman, R. B., Reinsch, T. G. (2002): Bulk Density and Linear Extensibility. - In: Dane, J. H., Topp, G. C. (eds.) Methods of Soil Analysis: Physical Methods. Part 4. Soil Science Society of America, Madison, WI, pp. 201-228.

[22] Guvenc, İ. (2019): Tomato production in Turkey, foreign trade and competitiveness. KSU J. Agric Nat 22(1): 57-61. DOI: 10.18016/ksutarimdoga.vi.432316.

[23] Harmanto, V. M., Salohke, V. M., Babel, M. S., Tantau H. J. (2005): Water requirement of drip- irrigated tomatoes grown in the greenhouse in tropical environment. Agricultural Water Management 71(3): 225-242. DOI: 10.1016/j.agwat.2004.09.003.

[24] Hartz, T. K., Miyao, E. M., Davis, R. M., Kochi, M. (2006): Influence of mustard cover crops on processing tomato production in the lower Sacramento Valley of California. Proceedings of the 9th ISHS Symposium on the Processing Tomato, Acta Horticulturae.

[25] Hashem, M. S., El-Abedin, T. Z., Al-Ghobari, H. M. (2018): Rational water use by applying regulated deficit and partial root-zone drying irrigation techniques in tomato under arid conditions. - Chilean Journal of Agricultural Research 79(1). DOI: 10.4067/S0718-58392019000100075.

[26] Hatfield, J. L., Dold, C. (2019): Water-use efficiency: advances and challenges in a changing climate. - Front. Plant Sci. https://doi.org/10.3389/ fpls. 2019.00103.

[27] Helyes, L., Lugasi, A., Pek, Z. (2012): Effect of irrigation on processing tomato yield and antioxidant components. - Turkish Journal of Agricultural and Forestry 36: 702-709. DOI: 10.3906/tar-1107-9.

[28] Hernández-Suárez, M. H., Rodríguez, E. R., Romero, C. D. (2008): Chemical composition of tomato (Lycopersicon esculentum) from Tenerife, the Canary Islands. Food Chem 106(3): 1046-1056. http://dx.doi.org/10.1016/j.foodchem.2007.07.025.

[29] Howell, T. A. (2001): Enhancing water use efficiency in irrigated agriculture. - Agron. J. 93: 281-289.

[30] Huang, S., Zhao, C., Zhang, Y., Wang, C. (2018): Nitrogen Use Efficiency in Rice. - In: Amaullah, Fahad, S. (eds.) Nitrogen in Agriculture-Updates. InTech, Christchurch, New Zealand.

[31] Ismail, S., Ozawa, K., Khondaker, N. A. (2007): Effect of irrigation frequency and timing on tomato yield, soil water dynamics and water use efficiency under drip irrigation. Eleventh International Water Technology Conference, IWTC11 2007 Sharm El-Sheikh, Egypt.

[32] Keller, J., Bliesner, R. D. (1990): Sprinkle and Trickle Irrigation. - Van Nostrand Reinhold, New York.

[33] Kırnak, H., Kaya. C. (2004): Determination of irrigation scheduling of tomato using panevaporation in Harran plain. GOÜ. - Journal of Agricultural Engineering 21(1): 43-50.

[34] Kuo, S. (1996): Phosphorus. - In: Sparks, D. L. (ed.) Methods of Soil Analysis. Part 3: Chemical Methods. SSSA Book Ser. 5. SSSA and ASA, Madison, WI. pp. 869-919. DOI: 10.2136/sssabookser5.3.c32.

[35] Kuşçu, H., Karasu, A., Öz, M., Demir, A. O., Turgut, İ. (2013): Effect of irrigation amounts applied with drip irrigation on maize evapotranspiration, yield, water use efficiency, and net return in a sub-humid climate. - Turkish Journal of Field Crops 18(1): 13-19.

[36] Kuş̧̧u, H., Turhan, A., Demir, A. O. (2014): The response of processing tomato to deficit irrigation at various phenological stages in a sub-humid environment. - Journal of Agricultural Water Management 133: 92-103.

[37] Lisar, S. Y. S., Motafakkerazad, R., Hossain, M. M., Rahman, I. M. M. (2012): Water Stress in Plants: Causes, Effects and Responses. - In: Rahman, I. M. M., Hasegawa, H. (eds.) Water Stress. Chap. 1. InTech, Rijeka, pp. 1-14. DOI: 10.5772/39363.

[38] Locascio, S. J., Smajstrla, A. G. (1996): Water application scheduling by pan evaporation for drip-irrigated tomato. - JASHS 121(1): 63-68.

[39] Locascio, S. J., Olson, S. M., Rhoads, F. M. (1989): Water quantity and time of N and K application for trickle-irrigated tomatoes. - J. Amer. Soc. Hort. Sci. 114: 265-268. 
[40] Loeppert, R. H., Suarez, D. L. (1996): Carbonate. - In: Sparks, D. L., et al. (eds.) Methods of Soil Analysis. Part 3: Chemical Methods. ASA and SSSA, Madison, WI, pp. 437-474.

[41] Machade, R., Oliviera, M. R. G. (2005): Tomato root distribution, yield and fruit quality under different subsurface drip irrigation regimes and depths. - Irrigation Science 24(1): 15-24. DOI: 10.1007/s00271-005-0002-z.

[42] Mahajan, G., Singh, K. G. (2006): Response of greenhouse tomato to irrigation and fertigation. - Agricultural Water Management 84: 202-206.

[43] Malash N. M., Flowers T. J., Ragab, R. (2008): Effect of irrigation methods, management and salinity of irrigation water on tomato yield, soil moisture and salinity distribution. Irrigation Science 26(4): 313-323.

[44] Marouelli, W. A., Silva, W. L. C., Moretti, C. L. (2004): Production, quality and water use efficiency of processing tomato as affected by the final irrigation timing. - Hortic. Bras. 22(2). http://dx.doi.org/10.1590/S0102-05362004000200013.

[45] Medrano, H., Tomas, M., Martorell, S., Flexas, J., Hernandez, E., Rosello, J., Escalona, J. M., Bota, J. (2015): From leaf to whole plant water efficiency (WUE) in complex canopies: limitations of leaf WUE as a selection target. - The Crop Journal 3(3): 220-228. https:77doi.org/10.1016/j.cj.2025.04.00.

[46] Mitchell, J. P., Shennan, C., Grattan, S. R., May, D. M. (1991): Tomato yields and quality under water deficit and salinity. - J. Amer. Soc. Hort. Sci. 116: 215-221.

[47] Mohammed, H. N., Mahmud, T. M. M., Puteri Edaroyati, M. W. (2018): Deficit irrigation for improving the postharvest quality of lowland tomato fruits. - Pertanika J. Trop. Agric. Sci. 41(2): 741-758.

[48] Mohammed, M., Wilson, L. A., Gomes, P. L. (1999): Postharvest sensory and physiochemical attributes of processing and non-processing tomato cultivar. - J. Food Qual. 22: 167-182. DOI: 10.1111/j.1745-4557.1999.tb00549.x.

[49] Musyoka, M., Adamtey, N., Muruiki A. W., Bautze D., Karanje E., Mucheru-Muna M., Fiaboe K. K. M., Cadisch G. (2019): Nitrogen leaching losses and balances in conventional and organic farming systems in Kenya. - Nutrient Cycling in Agroecosystems. DOI: 10.1007/s10705-019-10002-7.

[50] Nelson, D. W., Sommers, L. E. (1996): Total Carbon, Organic Carbon, and Organic Matter. - In Sparks, D. L. et al. (eds.) Methods of Soil Analysis. Part 3. SSSA Book Series, Madison, WI, pp. 961-1010.

[51] Nuruddin, M. M., Madramootoo, C. A., Dodds, G. T. (2003): Effects of water stress at different growth stages on greenhouse tomato yield and quality. - Journal of Hort. Science 38(7): 1389-1393.

[52] Oenema, O., Brentrup, F., Lammel, J., Bascou, P., Billen, G., Dobermann, A., Erisman, J. W., Garnett, T., Hammel, M., Haniotis, T., Hillier, J., Hoxha, A., Jensen, L. S., Oleszek, W., Pallière, C., Powlson, D., Quemada, M., Schulman, M., Sutton, M. A., Van Grinsven, H. J. M., Winiwarter, W. (2015): EU Nitrogen Expert Panel, Nitrogen Use Efficiency (NUE) - An Indicator for the Utilization of Nitrogen in Agriculture and Food Systems. Wageningen University, Wageningen.

[53] Olson, S. M., Rhoads F. M. (1992): Effect of water quantity on fall tomato production in North Florida. - Proceedings of Florida State Horticultural Society 105: 334-336.

[54] Patanè, C., Cosentino, S. L. (2010): Effects of soil water deficit on yield and quality of processing tomato under a Mediterranean climate. - Agr. Water Manage. 97: 131-8.

[55] Patanè, C., Tringali, S., Sortino, O. (2011): Effects of deficit irrigation on biomass, yield, water productivity and fruit quality of processing tomato under semi-arid Mediterranean climate conditions. $\quad-$ Scientia Horticulturae 129(4): 590-596. https://doi.org/10.1016/j.scienta.2011.04.030.

[56] Rhoades, J. D. (1996): Salinity: Electrical Conductivity and Total Dissolved Solids. - In: Sparks, R. L. (ed.) Methods for Soil Analysis. Part 3: Chemical Methods. Soil Science Society of America, Madison, WI, pp. 417-435. 


$$
-1862 \text { - }
$$

[57] Rotiroti, M., Bonomi, T., Sacchi, E., McArthur, J. M., Stefania, G. A., Zanotti, C., Taviani, S., Patelli, M., Nava, V., Soler, V., Fumagalli, L., Leoni, B. (2019): The effects of irrigation on groundwater quality and quantity in a human-modified hydro-system: the Oglio River basin, Po Plain, northern Italy. - Science of the Total Environment 672: 342 356.

[58] Senyigit, U., Arslan, M. (2018): Effects of irrigation programs formed by different approaches on the yield and water consumption of black cumin (Nigella sativa L.) under transition zone in the West Anatolia conditions. - Journal of Agricultural Sciences 24: 22-32.

[59] Shock, C. (2006): Drip Irrigation: An Introduction. - Oregon State University, Corvallis. https://catalog.extension.oregonstate.edu/sites/catalog/files/project/pdf/em8782.pdf (accessed on 13.07.2012).

[60] Shrivastava, P., Kumar, R. (2015): Soil salinity: a serious environmental issue and plant growth promoting bacteria as one of the tools for its alleviation. - Saudi Journal of Biological Sciences 22(2): 123-131. DOI: 10.1016/j.sjbs.2014.12.001.

[61] Smajstrla, A. G., Locascio S. J. (1989): Drip irrigated tomato as affected by water quantity by $\mathrm{N}$ and $\mathrm{K}$ application timing. - Proceedings of Florida State Horticultural Society 102: 307-309.

[62] Smajstrla, A. G., Locascio S. J. (1990): Irrigation scheduling of drip irrigated tomato using tensiometers. - Proc. Florida State Hort. Soc. 103: 88-91.

[63] Soil Survey Staff. (2014): Keys to Soil Taxonomy. 12th Ed. - USDA-Natural Resources Conservation Service, Washington, DC.

[64] SPSS (2008): SPSS Statistics for Windows, Version 17.0. - SPSS Inc., Chicago.

[65] Thapa, B., Scott, C. A. (2019): Institutional strategies for adaptation to water stress in farmer-managed irrigation systems of Nepal. - International Journal of the Commons 13(2): 892-908. DOI: http://doi.org/10.5334/ijc.901.

[66] Thomas, G. W. (1996): Soil pH and Soil Acidity. - In Sparks, D. L. (ed.) Methods of Soil Analysis. Part 3: Chemical Methods. SSSA Book Ser. 5. SSSA, Madison, WI, pp. 475490.

[67] Xu, L., Niu H., Xu, J., Wang X. (2013): Nitrate-nitrogen leaching and modeling in intensive agriculture farmland in China. - The Scientific World Journal. http://dx.doi.org/10.1155/2013/353086.

[68] Wahb-Allah, M. A., Al-Omran, A. M. (2012): Effect of water quality and deficit irrigation on tomato growth, yield and water use efficiency at different developmental stages. - Journal of Agricultural \& Environmental Sciences 11(2): 80-109.

[69] Yurtseven, E., Kesmez, G. D., Ünlükara, A. (2005): The effects of water salinity and potassium levels on yield, fruit guality and water consumption of a native central anatolian tomato species (Lycopersicon esculentum). - Agricultural Water Management 78: $128-135$.

[70] Zegbe-Dominguez, J. A., Behboudian, M. H., Lang, A., Clothier, B. E. (2003): Deficit irrigation and partial rootzone drying maintain fruit dry mass and enhance fruit quality in "Petopride" processing tomato (Lycopersicon Esculentum, Mill.). - Journal of Scientia Horticulturae 98(4): 505-510. 